\title{
Uji Efek Antiangiogenesis Menggunakan Metode Chorio Allantoic Membrane dari Ekstrak Etanol Daun Talas (Colocasia esculenta L. Schott)
}

\author{
Moh Iqbal ${ }^{1}$, Muhammad Yusuf $^{*}$, Hendra Herman $^{1}$, Andi Emelda ${ }^{1}$ \\ ${ }^{1}$ Program Studi S1 Farmasi, Fakultas Farmasi, Universitas Muslim Indonesia, Makassar, Indonesia \\ 2 Program Studi S1 Farmasi, Fakultas Farmasi, Universitas Megarezky, Makassar, Indonesia
}

DOI : https://doi.org/10.29303/sjp.v1i2.36

\section{Article Info}

Received : 2020-07-27

Revised : 2020-09-28

Accepted : 2020-09-28

\begin{abstract}
Abstrak: The Antiangiogenesis according to in vivo ethanol extract of taro leaves (Colocasia esculenta L. Schott) with Chorio Allantoic Membrane (CAM) method. Angiogenesis is aformation process of new capillaries contained in the vascular system. Taro leaves (Colocasia esculenta L.Schott) contain flavonoids are thought to have an antiangiogenesis effect. Research aims to look the potential antiangiogenesis of ethanol extract of taro leaves (Colocasia esculenta L. Schott) with Chorio Allantois Membrane (CAM) method and determine the concentration of extract taro leaves (Colocasia esculenta L. Schott) potential as antiangiogenesis. The antiangiogenesis Chorio Allantoic Membrane (CAM) using chicken eggs 9 days old. Research divided the eggs into 4 groups, one control group without treatment and 3 group as treatment control. The control group was treated with a concentration of $1 \mathrm{ug} / \mathrm{ml}, 10 \mathrm{mg} / \mathrm{ml}$ and $100 \mathrm{mg} / \mathrm{ml}$. The eggs were incubated for 72 hours.Research conducted by macroscopic observation semiquantitative score. In the untreated control group scored 5 and treatment groups at a concentration of $1 \mathrm{ug} / \mathrm{ml}$ scored 5 , the concentration of $10 \mathrm{ug} / \mathrm{ml}$ scored 1 and a concentration of $100 \mathrm{ug} / \mathrm{ml}$ scored 0 . The results showed that the extract concentration which given antiangiogenesis effect is on concentration of $10 \mathrm{ug} / \mathrm{ml}$ and $100 \mathrm{ug} / \mathrm{ml}$ and the extract concentration that effectively inhibit antiangiogenesis at concentration of $100 \mathrm{ug} / \mathrm{ml}$. It can be concluded that the greater the number of extract concentration is entered, the diminishing number of blood vessels that grow and obtain lower scores.
\end{abstract}

Keywords: Angiogenesis, Chorio allantoic membrane (CAM), Colocasia esculenta L. Schott.

Citation: Iqbal, M., Yusuf, M., Herman, H., Emelda, A. (2020). Uji Efek Antiangiogenesis Menggunakan Metode Chorio Allantoic Membrane dari Ekstrak Etanol Daun Talas (Colocasia esculenta L. Schott). Sasambo Journal of Pharmacy, 1(2), 51-56. doi : https:// doi.org/10.29303/sjp.v1i2.36

\section{Pendahuluan}

Kanker adalah suatu pertumbuhan atau pembengkakan massa dari sel yang abnormal dan bersifat ganas. Sel kanker tumbuh dan berkembang dengan mengambil nutrisi dan oksigen dari inang (host) dengan cara membentuk pembuluh darah baru (angiogenesis) dari pembuluh darah yang sudah ada. Penghambatan proses angiogenesis dari kanker akan menyebabkan sel kanker mengalami penghambatan pertumbuhan, kelaparan dan akhirnya mati.
Angiogenesis diketahui merupakan kunci bagi perkembangan kanker (Giavazzi et al., 2000). Angiogenesis merupakan peristiwa pertumbuhan pembuluh darah baru (neovaskularisasi), memungkinkan sel mendapatkan suplai nutrien dan oksigen, sehingga dapat terus bertahan hidup (Hanahan dan Weinberg, 2000).

Antiangiogenesis adalah terapi yang bertujuan untuk menghentikan pembentukan pembuluh darah baru, karena tanpa suplai darah, sel tumor atau kanker akan mati Tanpa memiliki pembuluh darah sendiri 
tumor hanya dapat tumbuh 1 milimeter saja (Rahayu, 2014).

Pada Chorio Allantoic Membrane (CAM) embrio, uji antiangiogenesis secara in vivo menggunakan metode Chorio Allantois Membrane (CAM) karena vaskularisasi yang luas, mudah dilihat, mudah dijangkau, murah, masa eksperimen lebih pendek, dan diferensi pembuluh darah yang baik. Hal ini mendorong peneliti untuk melakukan uji pendahuluan untuk melakukan pencarian senyawa baru yang dapat menghambat pertumbuhan sel tumor/kanker, dari tanaman yang mungkin nantinya dapat ditingkatkan pemanfaatannya sebagai salah satu tumbuhan obat yang berkhasiat sebagai antikanker. Salah satu tanaman yang banyak digunakan oleh masyarakat adalah talas (Colocasia esculenta L. Schott) untuk pengobatan antikanker, antibakteri dan antijamur, diabetes, obat cacing, antihipertensi, efek diuretik dan antiinflamasi (Halligudi, 2013; Mustafida Dkk, 2014).

Pada penelitian yang dilakukan oleh Patil B.R., dan Ageely H.M (2011) tentang anti-hepatotoksik, dan Halligudi S, (2013) melakukan penelitian tentang isolasi kandungan senyawa pada tanaman talas (Colocasia esculenta L. Schott) yang mengandung berbagai komponen aktif biologis yaitu flavanoid, triterpenoid, glikosida mineral dan mikronutrien. Pada penelitian pengujian toksisitas ekstrak etanol daun talas (Colocasia esculenta L. Schott) dengan metode BSLT (Brine shrimp Lethality Test) yang dilakukan oleh Fauzia (2014) dapat disimpulkan bahwa ekstrak etanol daun talas (Colocasia esculenta L.schott) bersifat toksik dengan nilai yaitu sebesar $16,848 \mu \mathrm{g} / \mathrm{ml}(7,314 \mu \mathrm{g} / \mathrm{ml}-$ $37,455 \mu \mathrm{g} / \mathrm{ml}$ ) dan berpotensi sebagai antikanker. Dari berbagai penelitian, manfaat talas dapat ditingkatkan penggunaannya untuk pengembangan obat tradisional.

Berdasarkan uraian tersebut, untuk mengoptimalkan pemanfaatan daun talas (Colocasia esculenta L. Schott) sebagai sumber bahan obat maka peneliti berencana melakukan uji antiangiogenesis secara in vivo ekstrak etanol daun talas (Colocasia esculenta L. Schott) dengan metode Chorio Allantoic Membrane (CAM) dengan menggunakan telur dengan tujuan untuk menguji antiangiogenesis ekstrak etanol daun talas (Colocasia esculenta L. Schott) dengan metode Chorio Allantois Membrane (CAM) secara makroskopik dan untuk menentukan konsentrasi ekstrak yang berpotensi sebagai antiangiogenesis dengan dengan metode Chorio Allantois Membrane (CAM).

\section{Metode \\ Bahan dan Alat}

Alat-alat yang akan dipakai pada penelitian ini adalah alat-alat gelas (phyrex), gunting, Menidril, Neraca analitik, Rotavapor, Seperangkat alat maserasi, seperangkat alat penetesan, spoit, Termometer, Timbangan O'haus dan Vial.

Bahan-bahan yang digunakan pada penelitian ini Aquadest, Ekstrak etanol daun talas (Colocasia esculenta L. Schott), Etanol 70 \%, Na-CMC, Parafin, Paper disc, telur ayam kampung.

\section{Penyiapan Alat dan Bahan}

Seperangkat alat maserasi, lalu bahan seperti etanol $70 \%$, dan telur ayam kampng yang masih berusia 1 hari disiapkan terlebih dahulu untuk jalannya penelitian.

\section{Pengambilan dan Pengolahan Sampel \\ Pengambilan sampel}

Sampel Daun talas (Colocasia esculenta L. Schott) diambil di daerah Kel. Tamalanrea, Kec. Tamalanrea kota Makassar .

\section{Pengolahan sampel}

Sampel Daun talas (Colocasia esculenta L. Schott) dikumpulkan, setelah itu dibersihkan dari kotoran-kotoran yang melekat, setelah itu daun yang telah dibersihkan kemudian di potong-potong kecil dan diangin-anginkan selama beberapa hari (tidak boleh terkena sinar matahari langsung), kemudian diserbukkan dengan menggunakan blender setelah itu ditimbang kembali berat serbuk, kemudian dimaserasi dengan menggunakan pelarut etanol $70 \%$ (Yusuf \& Alyidrus, 2020; Yusuf \& Wati, 2019).

\section{Pembuatan Sampel}

Sampel Daun talas (Colocasia esculenta L. Schott) yang telah dikeringkan ditimbang sebanyak 300 gram dimasukkan ke dalam wadah maserasi, lalu ditambahkan pelarut etanol $70 \%$ sebanyak $4.000 \mathrm{~mL}$ hingga simplisia tersebut terendam, dibiarkan selama 3 hari dalam bejana tertutup dan terlindungi dari cahaya matahari langsung sambil diaduk secara periodik, setelah $3 \times 24$ jam dilakukan penyaringan untuk diperoleh ekstrak etanol cair. Hasil penyarian yang diperoleh kemudian diuapkan dengan menggunakan rotavapor hingga diperoleh ekstrak kental (Yusuf \& Alyidrus, 2020; Yusuf \& Wati, 2019).

\section{Pemilihan Sampel Uji}

Sampel yang digunakan dalam penelitian ini adalah telur ayam kampung yang berumur 1 hari.

\section{Pembuatan Bahan Penelitian \\ Pembuatan Larutan Na-CMC 1\% b/v}

Sebanyak 1 gram Na-CMC dimasukkan sedikit demi sedikit ke dalam $50 \mathrm{ml}$ air suling panas sambil diaduk dengan menggunakan pengaduk elektrik 
hingga terbentuk larutan yang homogen, kemudian dicukupkan volumenya hingga $100 \mathrm{ml}$.

\section{Pembuatan sediaan ekstrak}

Sebanyak $50 \mathrm{mg}$ ekstrak etanol daun talas (Colocasia esculenta L. Schott) ditimbang dan dilarutkan dalam $50 \mathrm{ml} \mathrm{Na}-\mathrm{CMC}$, kemudian dipipet $1 \mathrm{ml}$ dari larutan stok, lalu dicukupkan $10 \mathrm{ml}$ dengan $\mathrm{Na}-\mathrm{CMC}$ sampai batas tanda sehingga konsentrasinya menjadi $100 \mu \mathrm{g} / \mathrm{ml}$. Setelah itu dipipet $1 \mathrm{ml}$ (larutan konsentrasi $100 \mu \mathrm{g} / \mathrm{ml}$ ) dan kemudian dicukupkan kembali hingga $10 \mathrm{ml}$ dan didapatkan konsentrasi $10 \mu \mathrm{g} / \mathrm{ml}$. Lalu dipipet kembali $1 \mathrm{ml}$ (larutan konsentrasi $10 \mu \mathrm{g} / \mathrm{ml}$ ) dan dicukupkan hingga $10 \mathrm{ml}$ dan didapatkan konsentrasi $1 \mu \mathrm{g} / \mathrm{ml}$.

(Yusuf \& Alyidrus, 2020; Yusuf \& Wati, 2019).

\section{Pengujian Chorio Allantoic Membrane (CAM)}

Sampel uji yang digunakan dalam penelitian ini adalah telur ayam kampung yang berumur 1 hari. Kemudian telur ayam kampung tersebut diinkubasi pada suhu $39^{\circ} \mathrm{i} C$ dengan kelembaban $60 \%$, hingga berumur 9 hari. setelah di inkubasi rongga udara pada telur di tarik dengan menggunakan spoit dengan posisi vertikal. Kemudian di buat lubang segiempat (jendela) berukuran $1 \times 1 \mathrm{~cm}$ pada kerabang telur dengan posisi horisontal. Setelah itu sampel dibagi menjadi 4 kelompok yaitu, kelompok I adalah kelompok tanpa perlakuan. Kelompok II ,III dan IV merupakan kelompok yang diberi ekstak etanol daun talas (Colocasia esculenta L. Schott) dengan masing-masing konsentrasi $1 \mu \mathrm{g} / \mathrm{ml}, 10 \mu \mathrm{g} / \mathrm{ml}$ dan $100 \mu \mathrm{g} / \mathrm{ml}$ setelah itu paper disk ditetesi dengan ekstrak etanol daun talas (Colocasia esculenta L. Schott) sebanyak 3 tetes, kemudian dimasukkan ke dalam telur dan lubang (jendela) pada telur di tutup kembali dengan menggunakan parafin. Telur yang telah berisi paper disk di inkubasi kembali selama $3 \times 24$ (3 hari). Dan diamati penghambatan pembuluh darah secara makroskopik (Mustafida Dkk, 2014; Yusuf, 2020).

\section{Pengumpulan dan Analisis Data}

Untuk mengetahui pengaruh antiangiogenesis pada telur dapat diamati secara makroskopik.

\section{Hasil dan Pembahasan}

Hasil pengujian ekstrak etanol daun talas (Colocasia esculenta L. Schott ) menggunakan metode Chorio Allantoic Membrane (CAM) dapat dilihat pada gambar berikut ini :

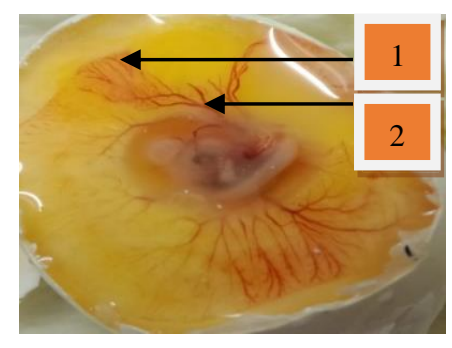

Gambar 1. Kontrol tanpa perlakuan pada telur ayam Keterangan :

1. Pembuluh darah kecil

2. Pembuluh darah besar

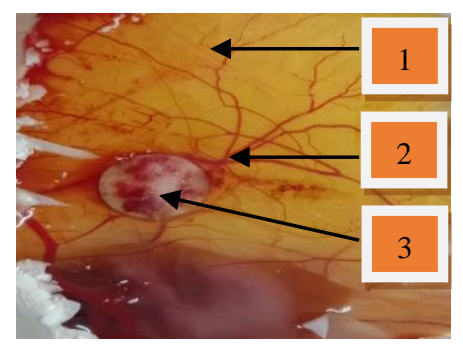

Gambar 2. Kontrol perlakuan dengan ekstrak etanol daun talas konsentrasi $1 \mu \mathrm{g} / \mathrm{ml}$ pada telur ayam

Keterangan :

1. Pembuluh darah kecil

2. Pembuluh darah besar

3. Paper disc yang telah diinduksi ekstrak daunt alas konsentrasi $1 \mu \mathrm{g} / \mathrm{ml}$

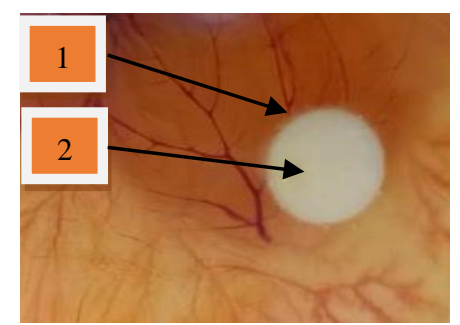

Gambar 3. Kontrol perlakuan dengan ekstrak etanol daun talas konsentrasi $10 \mu \mathrm{g} / \mathrm{ml}$ pada telur ayam

Keterangan :

1. Pembuluh darah kecil

2. Paper disc yang telah diinduksi ekstrak daunt alas konsentrasi $10 \mu \mathrm{g} / \mathrm{ml}$

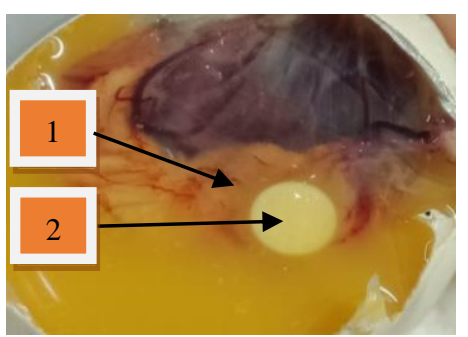

Gambar 4. Kontrol perlakuan dengan ekstrak etanol daun talas konsentrasi $100 \mu \mathrm{g} / \mathrm{ml}$ pada telur ayam 
Keterangan :

1. Pembuluh darah kecil

2. Paper disc yang telah diinduksi ekstrak daunt alas konsentrasi $100 \mu \mathrm{g} / \mathrm{ml}$

Hasil penelitian berdasarkan pemberian skor pada uji antiangiogenesis ekstrak etnaol daun talas (Colocasia esculenta L.Schott) menggunakan metode Chorio Allantoic Membrane (CAM) dapat dilihat pada tabel 1:

Tabel 1. Pemberian skor Chorio Allantoic Membrane (CAM) secara macroscopic semiquantitative score dengan perlakuan ekstrak etanol daun talas dengan berbagai variasi konsentrasi

\begin{tabular}{cc}
\hline Konsentrasi $\mu \mathrm{g} / \mathrm{ml}$ & Skor \\
\hline 100 & 0 \\
10 & 1 \\
1 & 5 \\
Tanpa perlakuan & 5 \\
\hline
\end{tabular}

Pada penelitian ini dilakukan uji antiangiogenesis secara in vivo ekstrak etanol daun talas (Colocasia Esculenta L.Schott) dengan menggunakkan metode Chorio Allantoic Membrane (CAM). Penelitian ini merupakan penelitian secara in vivo menggunakan metode Chorio Allantoic Membrane (CAM), metode ini pertama kali dikemukakan oleh Ribbati (1997) yang merupakan metode pendekatan untuk mengetahui adanya perubahan-perubahan pada pembuluh darah dari membran korio alantois akibat perlakuan tertentu. Penelitian ini mengikuti metode yang sama dengan sedikit modifikasi yaitu tidak menggunakan gelatin sponges sebagai pembawa sediaan uji tetapi menggunakan paper disc.

Pada penelitian ini digunakan telur ayam karena pada pembuluh darah pada Chorio Allantoic Membrane (CAM) embrio ayam pembuluh darahnya kuat dan permebeabiltasnya normal sedangkan pada pembuluh darah pada kanker struktur anatomi darahnya mudah rapuh dengan permeabilitasnya tinggi. Model angiogenesis pada Chorio Allantoic Membrane (CAM) paling baik digunakan karena secara tehnik lebih mudah dan murah (Mustafida Dkk, 2014).

Hasil pengujian ekstrak etanol daun talas (Colocasia esculenta L. Schott) menggunakan metode Chorio Allantoic Membran (CAM) dapat dilihat pada gambar 1, gambar 2, gambar 3 dan gambar 4. Dari hasil pengujian pada gambar 2 pada kontrol tanpa perlakuan pada telur ayam kampung jumlah pembuluh darahnya sangat banyak dan terdapat pembuluh darah besar dan pembuluh darah kecil artinya embrio anak ayam tersebut dapat berkembang dengan baik. Pada gambar 3 kontrol perlakuan pada telur yang dimasukkan ekstrak dengan konsentrasi 1 $\mu \mathrm{g} / \mathrm{ml}$ jumlah pembuluh darahnya sangat banyak dan terdapat pembuluh darah besar dan kecil artinya embrio anak ayam dapat berkembang dengat baik dan tidak terjadi penghambatan. Pada gambar 4 Kontrol perlakuan pada telur ayam yang dimasukkan ekstrak daun talas dengan konsentrasi $10 \mu \mathrm{g} / \mathrm{ml}$ jumlah pembuluh darahnya sudah mulai berkurang dan hanya terdapat pembuluh darah kecil, artinya ekstrak daun talas pada konsentrasi $10 \mu \mathrm{g} / \mathrm{ml}$ sudah mulai menghambat pertumbuhan pembuluh darah. Pada gambar kontrol perlakuan pada telur ayam yang dimasukkan ekstrak dengan konsentrasi $100 \mu \mathrm{g} / \mathrm{ml}$ jumlah pembuluh darahnya yang tumbuh atau berkembang terhambat oleh adanya ekstrak daun talas dan hanya terdapat pembuluh darah kecil.

Berdasarkan hasil pengamatan secara macroscopic semiquantitative score, pada uji antingiogenesis dapat dilihat pada tabel 1, pada telur yang diberi ekstrak dengan konsentrasi $1 \mu \mathrm{g} / \mathrm{ml}$ memperoleh skor 5 karena jumlah pembuluh darah sangat banyak. Pada konsentrasi $10 \mu \mathrm{g} / \mathrm{ml}$ memperoleh skor 1 karena jumlah pembuluh darah mulai berkurang. Pada konsentrasi $100 \mu \mathrm{g} / \mathrm{ml}$ memperoleh skor 0 karena dapat terlihat dengan jelas bahwa pembuluh darah yang tumbuh atau berkembang terhambat oleh adanya ekstrak daun talas pembuluh darah terpotong atau terpisah menjadi beberapa bagian, dan kontrol tanpa perlakuan memperoleh skor 5 karena tidak terjadi penghambatan pertumbuhan pembuluh darah. Konsentrasi ekstrak menghambat pertumbuhan pembuluh darah yaitu pada konsentrasi $10 \mu \mathrm{g} / \mathrm{ml}$ dan kosentrasi $100 \mu \mathrm{g} / \mathrm{ml}$. Berdasarkan hasil penelitian tersebut menunjukkan bahwa semakin besar jumlah konsentrasi ekstrak daun talas yang dimasukkan, maka semakin berkurang jumlah pembuluh darah yang tumbuh dan skor semakin rendah.

Ekstrak etanol daun talas (Colocasia esculenta L.Schott) dapat menghambat proses angiogenesis pada Chorio Allantoic Membrane (CAM). Penghambatan angiogenesis oleh ekstrak ini diasumsikan disebabkan oleh kandungan kimia yang ada dalam daun talas (Colocasia esculenta L.Schott) yaitu senyawa flavanoid. Senyawa flavanoid dilaporkan dapat menghambat senyawa proangiogenik yaitu VEGF sehingga akan menghambat terjadinya angiogenesis (Dalimartha, 1999).

Pada penelitian yang lain flavonoid juga menunjukkan penghambatan VEGF Senyawa flavonoid juga dapat menghambat proliferasi melalui inhibisi proses oksidatif yang dapat menyebabkan inisiasi kanker, Flavonoid menghambat beberapa faktor angiogenik, seperti proliferasi, migrasi sel endotelial dan pembentukan pipa pembuluh darah. Pada proses 
angiogenesis, VEGF bertujuan meningkatkan permeabilitas vascular, meningkatkan proliferasi sel endotel, meningkatkan mitosis sel endotel, migrasi sel endotel, pembentukan lumen pembuluh darah baru, kemotaksis makrofag dan vasodilatasi (Mustafida Dkk, 2014).

Mekanisme penghambatan angiogenesis oleh ekstrak etanol daun talas (Colocasia esculenta L.Schott) pada Chorio Allantoic Membrane (CAM) belum dapat dipastikan, diduga dengan cara menghambat vascular endhothelial growth factor (VEGF). Walaupun demikian penelitian ini belum bisa menjelaskan senyawa bioaktif mana dalam daun talas (Colocasia esculenta L.Schott ) yang bersifat antiangiogenik (Mustafida Dkk, 2014 ; Yusuf \& Alyidrus, 2020).

Dalam hal ini dapat dilihat bahwa pada penelitian tersebut ekstrak daun talas dapat memberikan efek antiangiogenesis serta bersifat toksik pada konsentrasi $10 \mu \mathrm{g} / \mathrm{ml}$ dan 100. $\mu \mathrm{g} / \mathrm{ml}$. Hal Ini menunjukkan bahwa ekstrak daun talas dapat berpotensi sebagai anti kanker.

\section{Kesimpulan}

Hasil analisis dapat disimpulkan bahwa Ekstrak etanol daun talas Colocasia esculenta L.Schott) pada konsentrasi $10 \mu \mathrm{g} / \mathrm{ml}$ dan $100 \mu \mathrm{g} / \mathrm{ml}$ memiliki efek antiangiogenik pada Chorio Allantoic Membrane (CAM) pada embrio ayam dan konsentrasi ekstrak etanol daun talas (Colocasia esculenta L.Schott) yang efektif dalam menghambat angiogenesisi adalah pada konsentrasi $100 \mu \mathrm{g} / \mathrm{ml}$.

\section{References}

Akter A., Rahman S., Morshed Md.T., Hossain S., Jahan S., Swarna A., Rahmatullah M., 2013. Evaluation of Antihyperglycemic and Antinociceptive Potential of Colocasia esculenta (L.) Schott (Araceae) Leaves. (Online). (http:/ / web.b.ebscohost.com.ezproxy.ugm.ac.id /ehost/pdfviewer/pdfviewer?vid=4\&sid=774d 4 d39-56c4-46089f635f9a288911af@sessionmgr112\&hid=122) (Diakses 6 februari 2014).

Dalimartha, S. 2003. Atlas Tumbuhan Obat Indonesia. Jakarta: Puspa Swara

Dewanti, E., Issoeganti., dan Puniawati, N,2010. Angiogenesis Pada Membran Kolorioalantois Embrio Ayam Akibat Implantasi Tumor Payudara Tikus ( Rattus Novergicus L.) Dan Perlakuan Ekstrak Etanol Daun Benalu Teh, Jurnal Bahan Alam Indonesia, 7:202.
Direktorat Jendral Pengawasan Obat dan Makanan.,1986. Sediaan galenik. Jakarta : Departemen Kesehatan Republik Indonesia.

Dirjen POM., 1979. Farmakope Indonesia, edisi III.Jakarta : Departemen Kesehatan Republik Indonesia.

Dirjen POM., 2000. Parameter Standar Umum Ekstrak TumbuhanObat..Jakarta :Departemen Kesehatan Republik Indonesia.

Edith Cristina.L.C.Flavia Chiva.C.Flavia Angelica.M.F.Maria Palmira.D.G. Herrida Regina.N.S. 2009. BCOP and Het-CAM as Alternative Methods to Animal experimentation. Brazilian Journal of Pharmaceutical Science.

Harianto, N. 2009. Mengenal, Mencegah, Mengatasi Silent Killer Kanker. Semarang: Pustaka Widyamara.

Halligudi S., 2013. Pharmocological Potential of Calocasia an Edible Plant,(Online). (http://jddt.in/index.php/jddt/article/viewFile /18/26) (Diakses 6 Februari 2014).

Hamid, I.S., Nazar D.S., dan Ratnani, H., ,2013,Hambatan Ekspresi vascular Endhotial Growth Factor Oleh Ekstrak Daun Sambung Nyawa Pada Endotel Membran Korioalantois, $4: 86$.

Hanahan, D. Weinberg. 2000. The Hallmark of Cancer.

ITIS (Integrated taxonomi information system), 2013. (Online).

(http://www.itis.gov/servlet/SingleRpt/Single Rpt?search_topic $=$ TSN\&search_value $=42549$ )

(Diakses 12 februari 2014).

Lokman, N,A., Elder A.S.F., Ricciardelli,C., And Oehler M,K., 2012, Chick Chorioallantois Membrane (CAM) Assay As In Vivo Model To Study The Effect Of Newly Identified Molecules On Ovarian Cancer Invasion And Metastatis.

Mycek. 2001. Farmakologi Ulasan Bergambar. Penerbit Widya Medika.jakarta.

Mustafida Y,R., Munawir AL, and Dewi Rosita., 2014, Efek Antiangiogenik Ekstrak Etanol Mahkota Dewa (Phaleria Macropa (Scheff).Boerl.) pada Membran Kolorioalantois (Cam) Embrio Ayam, E-jurnal Pustaka Kesehatan, 2:5.

Mosmann, T. 1993. Rapid colorimetric Assay for cellular Growth and survival; Application to proliferation and Citotoxicity Assay.Journal of Immunological Methods. 65: 55.

Nurwantoro (ed)., 2003, Dasar Teknologi Hasil Ternak, Fakultas Peternakan Unioversitas Diponegoro, Semarang, Indonesia.

Patil B.R., Ageely H.M., 2011. Antihepatotoxic Activity of Colocasia esculenta Leaf Juice. Journal of Advanced Biotechnology Vol 2. 
Plank MJ, Sleeman BD. 2004.Tumour-induced angiogenesis: a review. J. Theo. Med.; 5: 137-53.

Rao, S., Surech, C,. 2000, In Vitro Anticancer And In Vivo Anti Angiogenic Activity Of Crude Leaf Exctracs Of Cassia Tora and Cassia Sophera.

Rahayu, T, 2014, Antiangiogenesis Kanker Mati Kelaparan (Online), (http://www.rumahkanker.com/pengobatan/k omplementer/17antiangiogenesis-kanker-matikelaparan) (diakses 23 Juni 2014).

Ribatti Dominico. 2010. The Chick Embryo Chorioallantoic Membrane In The Study of angiogenesis and Metastatis. Springer Science.New York.

Rizal, Y. 2006. Ilmu Nutrisi Unggas. Andalas University Press, Padang.

Tannock IF., RP. Hill, RG. Bristow. 2005. BasicScience of Oncology. 4th ed. New York, NY: McGraw-Hill.

Wardiono, 2014. Detil data Colocasia Esculenta (L.) Schott. Prosea (Online) (http://www.proseanet.org/prohati2/browser.p hp?docsid=477) (diakses 6 februari 2014)

Yusuf, M., \& Alyidrus, R. (2020). Uji Antiangiogenesis Secara In Vivo Ekstrak Etanol Biji Kopi Robusta (Coffea Robusta) dengan Metode Chorio Allantoic Membrane (CAM). Jurnal Farmasi Galenika (Galenika Journal of Pharmacy) (e-Journal), 6(1), 6369.

https://doi.org/10.22487/j24428744.2020.v6.i1.14 975

Yusuf, M., \& Wati, A. (2019). Efek Infus Kayu Secang (Caesalpinia sappan L.) Terhadap Penurunan Kadar Gula Darah Mencit (Mus musculus). Media Farmasi Poltekkes Makassar, XV(1), 1-8. 